\title{
Tissue-specific effects of leptin administration on the abundance of mitochondrial proteins during neonatal development
}

\author{
M G Gnanalingham, A Mostyn, J Wang, R Webb, D H Keisler ${ }^{1}$, \\ N Raver ${ }^{2}$, M C Alves-Guerra ${ }^{3}$, C Pecqueur ${ }^{3}$, B Miroux ${ }^{3}$, \\ T Stephenson and M E Symonds \\ Centre for Reproduction and Early Life, Institute of Clinical Research, University of Nottingham, Nottingham NG7 2UH, UK \\ ${ }^{1}$ Department of Animal Sciences, University of Missouri, Columbia, Missouri, USA \\ ${ }^{2}$ Institute of Biochemistry, Food Science and Nutrition, Faculty of Agricultural, Food and Environmental Quality Sciences, The Hebrew University of Jerusalem, \\ Rehovot, Israel \\ ${ }^{3}$ Faculté de Médecine Necker-Enfants-Malades, CNRS-UPR 9078, Paris, France \\ (Requests for offprints should be addressed to M E Symonds, Academic Division of Child Health, School of Human Development, Queen's Medical Centre, \\ University Hospital, Nottingham, Nottingham NG7 2UH, UK; Email: michael.symonds@nottingham.ac.uk)
}

\begin{abstract}
Many tissues undergo a rapid transition after birth, accompanied by dramatic changes in mitochondrial protein function. In particular, uncoupling protein (UCP) abundance increases at birth in the lung and adipose tissue, to then gradually decline, an adaptation that is important in enabling normal tissue function. Leptin potentially mediates some of these changes and is known to promote the loss of UCP1 from brown fat but its effects on UCP2 and related mitochondrial proteins (i.e. voltage-dependent anion channel (VDAC) and cytochrome $c$ ) in other tissues are unknown. We therefore determined the effects of once-daily jugular venous administration of ovine recombinant leptin on mitochondrial protein abundance as determined by immunoblotting in tissues that do (i.e. the brain and pancreas) and do not (i.e. liver and skeletal muscle) express UCP2. Eight pairs of 1-day-old lambs
\end{abstract}

received either $100 \mu \mathrm{g}$ leptin or vehicle daily for 6 days, before tissue sampling on day 7. Administration of leptin diminished UCP2 abundance in the pancreas, but not the brain. Leptin administration had no affect on the abundance of VDAC or cytochrome $c$ in any tissue examined. In leptin-administered animals, but not controls, UCP2 abundance in the pancreas was positively correlated with VDAC and cytochrome $c$ content, and UCP2 abundance in the brain with colonic temperature. In conclusion, leptin administration to neonatal lambs causes a tissuespecific loss of UCP2 from the pancreas. These effects may be important in the regulation of neonatal tissue development and potentially for optimising metabolic control mechanisms in later life.

Journal of Endocrinology (2005) 187, 81-88

\section{Introduction}

Leptin is a $16 \mathrm{kDa}$ polypeptide hormone which is principally synthesised and secreted by adipose tissue and acts to regulate energy homeostasis and a range of neuroendocrine and reproductive functions in the adult (Schwartz et al. 1996, Friedman \& Halaas 1998, Ahima \& Flier 2000). However, its exact role in the neonate has yet to be fully determined. In the human fetus, plasma leptin concentrations increase with gestational age (Yuen et al. 1999, Cetin et al. 2000). In the newborn sheep, plasma leptin concentrations decline during the immediate $6 \mathrm{~h}$ after birth to then increase up to 7 days of age (Bispham et al. 2002). These temporal changes in leptin coincide with development of the hypothalamic-pituitary-adrenal axis with respect to the regulation of cortisol production coincident with the rapid activation of uncoupling protein (UCP)-1, which is unique to brown adipose tissue (BAT) (Clarke et al. 1997a, Ricquier \& Bouillaud 2000), and is followed by the gradual loss of UCP1 (Clarke et al. 1997b). In the neonatal sheep, leptin administration results in reduced UCP1 mRNA and protein abundance, in conjunction with maintained colonic temperature and plasma non-esterified fatty acid (NEFA) concentration, therefore not affecting thermogenic potential (Mostyn et al. 2002). The peak in UCP1 abundance at birth is accompanied by parallel increases in other mitochondrial proteins including the voltage-dependent anion channel (VDAC) located on the outer mitochondrial membrane, and cytochrome $c$, present within the inter-membrane space (Mostyn et al. 2003). VDAC regulates the supply of mitochondrial ADP and ATP into and out off the mitochondria. VDAC is also 
a component of the mitochondrial permeability transition pore (MPTP), which is composed of a number of proteins which combine and make contact sites between the inner and outer mitochondrial membranes (Crompton 1999); there is evidence to suggest that the MPTP is utilised in some capacity during apoptosis in the release of cytochome $c$ from the mitochondria (Gottlieb 2000). There is potential for this event in all tissues, but the role of the MPTP has been most widely studied in organs most susceptible to ischaemic-reperfusion injury such as the heart (Crompton 1999). Cytochrome $c$ is an essential component of the mitochondrial respiratory chain and is an mobile electron transporter, involved in the electron transfer from complex III to complex IV (Ludwig et al. 2001, Jiang \& Wang 2004).

$\mathrm{UCP} 2$ is present in a large number of tissues with its abundance being greatest in the lung, pancreas and skeletal muscle (Fleury et al. 1997). In the case of the lung it has recently been established in the sheep that UCP2 abundance peaks soon after birth and then rapidly decreases over the first month of life (Gnanalingham et al. 2005). This developmental pattern of expression is similar to that described for UCP1 in ovine BAT, suggesting UCP2 has a critical role in metabolic adaptation at birth. In this regard the high expression of UCP2 within the pancreas could be important in enabling the newborn to effectively adapt to the pronounced increase in plasma glucose concentration following the commencement of independent feeding (Phillips et al. 1978). The role of leptin in the abundance of UCP2, VDAC and cytochrome $c$ proteins has not been previously determined. Administration of leptin to $a b / o b$ mice, which do not produce leptin and are thus hypothermic, hyperphagic and obese, restores a normal body temperature, despite a $50 \%$ reduction in food intake (Pelleymounter et al. 1995). These changes in body temperature have been linked to increased abundance of UCP1 (Scarpace et al. 1997) and UCP2 (Gong et al. 1997) in BAT by some studies, but not by others (Memon et al. 2000). Moreover, these changes appear to be unique to rodents, as leptin treatment of large mammals, such as sheep and pigs, has been found to have a minor role in thermogenesis (Mostyn et al. 2002, Litten et al. 2004).

Leptin receptors are present in the $\beta$-cells of the pancreas, where UCP2 is also expressed (Kieffer et al. 1996, Chan et al. 1999). Leptin at physiological doses has been shown to inhibit both basal and glucose-stimulated insulin secretion in vitro (Emilsson et al. 1997, Roduit \& Thorens 1997), and to lower circulating insulin levels in vivo in adult rodents (Sivitz et al. 1997, Bryson et al. 1999). Levels of rat pancreatic islet UCP2 mRNA are enhanced by recombinant adenoviral-induced leptin expression (Zhou et al. 1997) and UCP2 has also been genetically linked to type II diabetes (Fleury et al. 1997). In the brain, UCP2 is expressed discretely in neurons located in the subcortical regions that are involved in the central regulation of autonomic and metabolic processes including thermogenesis, and UCP2-producing neurons have been found to be targets for peripheral hormones, including leptin (Horvath et al. 1999). In addition, i.c.v. leptin administration in rats causes depletion of adipocytes by apoptosis (Qian et al. 1998). Leptin has been proposed to increase glucose uptake in BAT and muscle and to reduce hepatic glycogen stores associated with increased glucose production (Nonogaki 2000). Liver UCP2 mRNA was increased by i.c.v. leptin administration in rats (Cusin et al. 1998), while skeletal muscle UCP2 mRNA was unaffected (Combatsiaris \& Charron 1999). Interestingly, interleukin- $1 \beta$ and tumour necrosis factor- $\alpha$, which regulate leptin (Zumbach et al. 1997, Faggioni et al. 1998b), have been shown to upregulate UCP2 mRNA in liver, muscle and adipose tissue of adult mice (Faggioni et al. 1998a), although there is now debate whether UCP2 is present in the liver and skeletal muscle (Pecqueur et al. 2001). No study to date has investigated the effect of chronic leptin administration on the abundance of UCP2 in the pancreas, liver, skeletal muscle and cerebral cortex in the neonatal period in a precocial species, such as the sheep.

The aims of this study were thus to determine whether maintaining high plasma leptin concentrations during neonatal development promotes the loss of the mitochondrial proteins UCP2, VDAC and cytochrome $c$ from either the pancreas, liver, skeletal muscle or brain (cerebral cortex) of neonatal sheep at 7 days postnatal age. This is the age when mitochondrial protein abundance is near maximal in many tissues including the lung and adipose tissue (Mostyn et al. 2003). In addition we determined whether any significant associations existed between these mitochondrial proteins and plasma leptin or NEFA concentrations and colonic temperature as measured through the study.

\section{Materials and Methods}

Full details of materials and methods have been previously published (Mostyn et al. 2002). In brief, eight pairs of weight-matched female triplet lambs were entered into the study. These were all conceived naturally and born normally at term to Bluefaced Leicester cross Swaledale ewes. Each lamb fed freely from their mother as they all remained with their mother throughout the study (including the one untreated triplet per ewe). At the end of the study the ewe kept the remaining triplet in order to avoid the need for the mother to prematurely cease lactating. Every lamb gained weight over the course of the study and there were no differences in growth rates between those treated with and without leptin. All operative procedures and experimental protocols had the required local ethical and Home Office approval as designated by the Animals (Scientific Procedures) Act of 1986. All pairs of lambs were selected on the basis of matched body weight $( \pm 10 \%)$ and a jugular vein catheter was inserted into each animal under local anaesthetic on day 1 of age (2\% xylocaine) to enable 
vehicle or leptin administration and blood sampling. The ovine leptin was produced recombinantly (Gertler et al. 1998). Lambs were entered into the study on day 1 of life and injected daily for 6 days at $\sim 0930 \mathrm{~h}$ with either

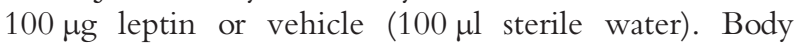
weight was measured daily and blood samples were taken on each study day before treatment. Colonic temperature was measured daily at $\sim 0900 \mathrm{~h}$ using a digital thermometer (VWR International, Leics, UK). On day 7, blood samples were taken at between 1100 and $1200 \mathrm{~h}$ from each lamb that was then humanely killed by i.v. administration of $100 \mathrm{mg} / \mathrm{kg}$ pentobarbital sodium (Euthatal: RMB Animal Health, UK). All major organs were rapidly removed, placed in liquid nitrogen and stored at $-70{ }^{\circ} \mathrm{C}$ until subsequent laboratory analysis.

\section{Laboratory analyses}

Protein detection Mitochondria were prepared from $1 \mathrm{~g}$ frozen head of pancreas, liver, skeletal muscle (i.e. quadriceps) and cerebral cortex area of the brain, and protein content of each preparation determined by the Lowry et al. (1951) method. Western blotting was utilised to measure the abundance of each protein. Following electroblotting of the polyacrylamide gel onto a nitrocellulose membrane, Ponceau red staining was used to visually confirm that similar amounts of protein had been transferred before subjecting the membranes to immunodetection (Mostyn et al. 2003). Abundance of cytochrome $c$ was determined on $10 \mathrm{mg}$ mitochondrial protein using an antibody (SC7159; Santa Cruz Biotechnology, Inc., Santa Cruz, CA, USA) at a dilution of 1 in 1000. VDAC abundance was determined using an antibody raised in rabbits to ovine VDAC, purified from the kidney of a newborn lamb as described by Mostyn et al. (2003), and was used at a dilution of 1 in 2000. Abundance of UCP2 was determined using the same antibody as described by Pecqueur et al. (2001), at a dilution of 1 in 10000 , which was raised against human UCP2. UCP2 was detected in the pancreas and cerebral cortex at 7 days of postnatal life, but not in skeletal muscle or liver, where the protein detected was not at the correct molecular mass, and hence was not UCP2 (Pecqueur et al. 2001, Mostyn et al. 2003). Densitometric analysis was performed using AIDA (Aida version 2.0; raytest Isotopenme $\beta$ geräte $\mathrm{GmBH}$, Straubenhardt, Germany) on each membrane following image detection using a Fujifilm LAS-1000 cooled CCD camera (Fuji Photo Film Co., Ltd, Tokyo, Japan) and all values are expressed in densitometric units. Specificity of detection was confirmed using non-immune rabbit serum. A range $(10-68 \mathrm{kDa})$ of molecular mass markers was included on all gels. All gels were run in duplicate and a reference sample (an appropriate ovine mitochondrial sample) was included on each to allow comparison between gels.

GDP binding The thermogenic activity of mitochondrial protein prepared from skeletal muscle as described above was assessed from the in vitro activity of the mitochondrial conductance pathway using GDP at a concentration of $2 \mathrm{mM}$, with non-specific binding measured using a $200 \mathrm{mM}$ concentration of GDP using the same methods described by Symonds et al. (1992). In addition, mitochondrial protein prepared from perirenal adipose tissue from a 1-day-old sheep acted as the positive control on this assay and all measurements were made in triplicate.

Plasma leptin, glucose and NEFA concentrations Plasma concentrations of glucose and NEFA were measured enzymatically (Clarke et al. 1994). Plasma leptin concentration was determined using a validated doubleantibody RIA as described by Delavaud et al. (2000). Plasma concentrations of leptin were assayed in duplicate $200 \mu \mathrm{l}$ samples using a rabbit anti-ovine leptin primary antibody, iodinated ovine leptin and sheep anti-rabbit secondary antibody. The limit of leptin detection was $0.1 \mathrm{ng} / \mathrm{ml}$ and the intra- and inter-assay coefficients of variation were $4 \cdot 2$ and $9 \cdot 1 \%(n=5)$ respectively.

\section{Statistical analyses}

All data are presented as means \pm S.E.M. Tests of normality as determined by the Kolmogorov-Smirnoff test revealed that the data were non-parametric. Statistically significant $(P<0 \cdot 05)$ differences between values obtained from vehicle-controls and leptin-treated groups were determined by the Mann-Whitney $U$ test and correlations within individual groups by Spearman's rank order test (SPSS v11·0; SPSS, Inc.).

\section{Results}

Daily jugular venous injection of leptin resulted in a persistent increase in plasma leptin throughout the course of the study (Fig. 1). Administration of leptin

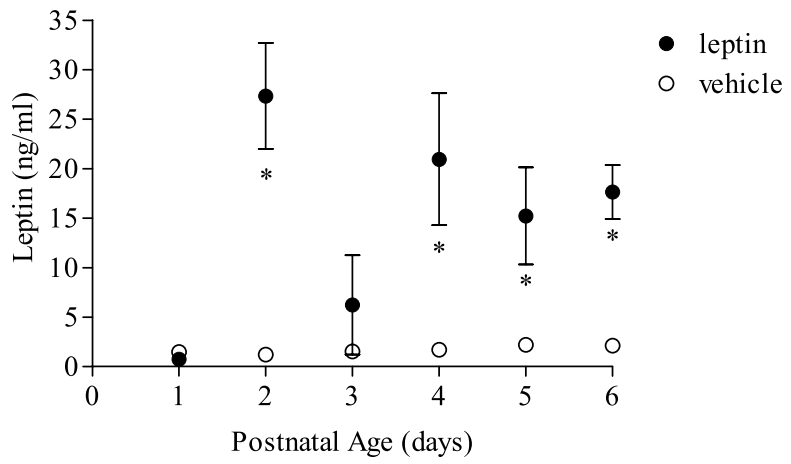

Figure 1 Effect of chronic daily ( 6 days) administration of leptin $(100 \mu \mathrm{g} /$ day $)$ on the plasma concentration of leptin as measured $<24 \mathrm{~h}$ after i.v. leptin injection in neonatal sheep. Values are means \pm S.E.M. ( $n=8$ per group). ${ }^{*} P<0 \cdot 05$, mean value significantly different from the vehicle-treated group. 


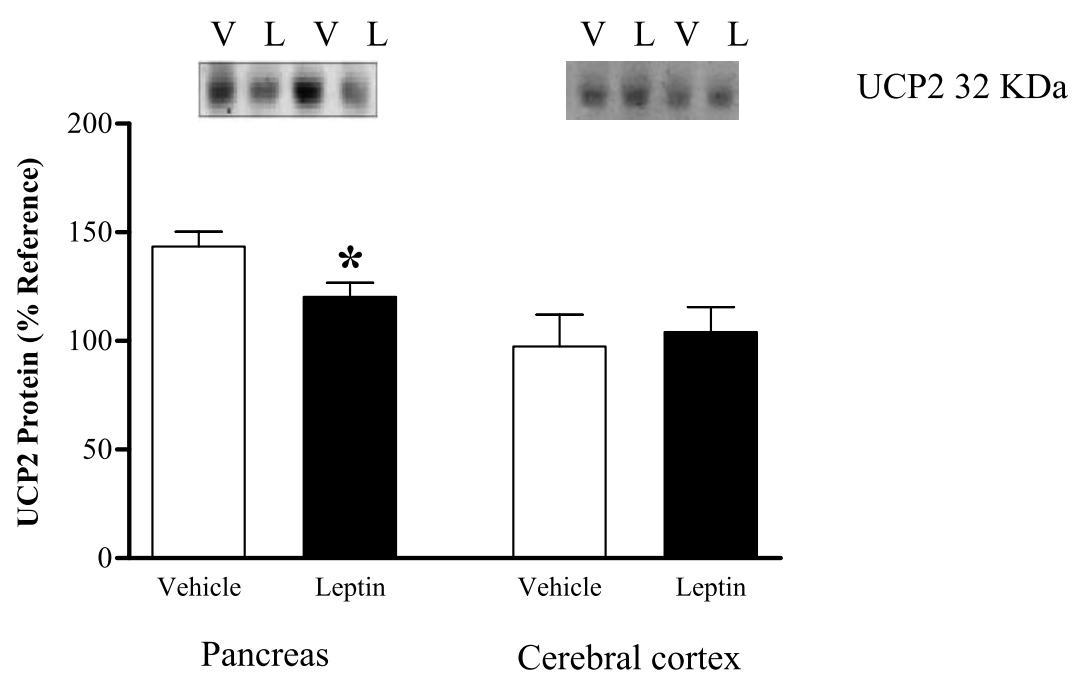

Figure 2 Effect of chronic (6 days) administration of leptin (100 $\mu \mathrm{g} /$ day) on the abundance of UCP2 in the pancreas and cerebral cortex of neonatal sheep sampled at 7 days postnatal age. Examples of protein expression are given. Values are means \pm S.E.M. ( $n=8$ per group). ${ }^{*} P<0 \cdot 05$, mean value significantly different from the vehicle-treated group.

resulted in a significant decrease $(P<0 \cdot 01)$ in UCP2 abundance in the pancreas at 7 days of postnatal age, but not in the cerebral cortex area of the brain (Fig. 2). In contrast, VDAC and cytochrome $c$ protein abundance were unaffected by leptin in all tissues studied (Table 1). GDP binding in skeletal muscle was unaffected by leptin (vehicle, $7 \cdot 8 \pm 0.6 \mathrm{pmol} / \mathrm{mg}$ mitochondrial protein; leptin, $8 \cdot 4 \pm 0 \cdot 6(n=8$ per group $))$ and was markedly lower than in BAT (vehicle, $44 \cdot 6 \pm 4.9 \mathrm{pmol} / \mathrm{mg}$ mitochondrial protein). Chronic leptin administration did not affect total body or tissue weights compared with controls (Table 2) or plasma glucose concentration throughout the study (e.g. day 4 vehicle, $5 \cdot 21 \pm 0.20 \mathrm{mM}$; leptin, $5 \cdot 5 \pm 0 \cdot 16)$.

A number of significant tissue-specific associations were observed between plasma leptin and NEFA concentrations and the physiological and molecular indices measured following leptin administration as outlined in Table 3. In the pancreas, UCP2 was positively associated with VDAC and cytochrome $c$ abundance following leptin administration, but negatively associated with VDAC in the vehicle group and mean plasma NEFA concentration over 7 days of leptin administration. VDAC abundance in the pancreas was also positively associated with plasma leptin on day 7 following leptin administration. In the liver, VDAC abundance was positively associated with plasma leptin on day 7 and with cytochrome $c$ content, whereas in skeletal muscle, plasma leptin on day 7 was positively associated with VDAC and cytochrome $c$ abundance following leptin administration, and negatively associated with cytochrome $c$ in the vehicle group. These associations observed following leptin administration were observed at the time at which plasma leptin was similar between groups (day 7 vehicle, $2 \cdot 0 \pm 0.3 \mathrm{ng} / \mathrm{ml}$; leptin, $2 \cdot 2 \pm 0 \cdot 3$ ) and is not unexpected as on the final day of the study all animals were sampled more than $24 \mathrm{~h}$ after the previous leptin injection. After leptin administration, mean colonic temperature over 7 days was positively associated with

Table 1 Abundance of the mitochondrial proteins VDAC and cytochrome $c$ in the pancreas, liver, skeletal muscle and cerebral cortex, as measured in neonatal sheep subjected to i.v. leptin $(100 \mu \mathrm{g} /$ day) administration or vehicle for 6 days. Values in arbitrary units are means \pm S.E.M., $n=8$ per group

\begin{tabular}{|c|c|c|c|c|}
\hline & \multicolumn{2}{|l|}{ VDAC } & \multicolumn{2}{|l|}{ Cytochrome c } \\
\hline & Vehicle & Leptin & Vehicle & Leptin \\
\hline \multicolumn{5}{|l|}{ Tissue } \\
\hline Pancreas & $191 \cdot 9 \pm 14 \cdot 2$ & $176 \cdot 2 \pm 25 \cdot 8$ & $140 \cdot 3 \pm 9 \cdot 7$ & $141 \cdot 7 \pm 10 \cdot 6$ \\
\hline Liver & $258 \cdot 2 \pm 34 \cdot 8$ & $240 \cdot 5 \pm 30 \cdot 9$ & $82 \cdot 7 \pm 5 \cdot 6$ & $80 \cdot 2 \pm 5 \cdot 8$ \\
\hline Skeletal muscle & $80 \cdot 7 \pm 11 \cdot 7$ & $81 \cdot 1 \pm 10 \cdot 0$ & $109 \cdot 5 \pm 12 \cdot 7$ & $103 \cdot 1 \pm 11 \cdot 3$ \\
\hline Cerebral cortex & $104 \cdot 8 \pm 13 \cdot 0$ & $98 \cdot 6 \pm 14 \cdot 3$ & $98 \cdot 1 \pm 8 \cdot 2$ & $101 \cdot 8 \pm 7 \cdot 3$ \\
\hline
\end{tabular}


Table 2 Mean body and organ weights as measured in 7-day-old neonatal sheep subjected to i.v. leptin $(100 \mu \mathrm{g} /$ day $)$ administration or vehicle for 6 days. Values are means \pm S.E.M., $n=8$ per group

\begin{tabular}{|c|c|c|}
\hline & Vehicle & Leptin \\
\hline Body weight (kg) & $5 \cdot 9 \pm 0 \cdot 4$ & $5 \cdot 6 \pm 0 \cdot 4$ \\
\hline Liver $(\mathrm{g})$ & $156 \cdot 9 \pm 9 \cdot 9$ & $165 \cdot 8 \pm 12 \cdot 4$ \\
\hline Brain (g) & $46 \cdot 8 \pm 1 \cdot 1$ & $48 \cdot 5 \pm 1 \cdot 4$ \\
\hline
\end{tabular}

GDP binding in skeletal muscle, and UCP2 abundance in the cerebral cortex.

\section{Discussion}

\section{Leptin and UCP2 in the neonatal pancreas}

In this study, we have shown for the first time that chronic leptin administration decreases UCP2 abundance in the neonatal pancreas. Importantly, this response were observed in the absence of any effect of leptin on food intake or behaviour (Mostyn et al. 2002). Our findings are therefore in agreement with the only report of UCP2 expression in human islets, demonstrating a $75 \%$ reduction in UCP2 mRNA expression following leptin administration in vitro (Brown et al. 2002). In contrast to our findings, Zhou et al. (1997) demonstrated that levels of rat pancreatic islet UCP2 mRNA and enzymes of fatty acid oxidation were enhanced by recombinant adenoviralinduced leptin expression. In the pancreas, the decreased UCP2 abundance with chronic leptin administration may improve insulin secretion and ameliorate the effects of type II diabetes, as reported in UCP2-deficient mice (Zhang et al. 2001). It is proposed that an absence of UCP2 leads to increased coupling in the $\beta$-cell mitochondria, causing higher ATP levels, inhibiting $\beta$-cell potassiumATP channels, depolarising the cell, leading to calcium influx through voltage-gated calcium channels, with this increased calcium leading to augmented insulin secretion (Zhang et al. 2001, Nedergaard \& Cannon 2003).

The functional relevance of the modest decrease in pancreatic UCP2 content following chronic leptin administration on $\beta$-cell function remains to be determined. It could act to modulate insulin secretion and aid normoglycaemia, thereby explaining why leptin administration had no adverse effect on plasma glucose in the present study. Acute and chronic leptin treatment lowers circulating insulin levels in rodents in vivo (Sivitz et al. 1997, Bryson et al. 1999), although this has not been confirmed in human islets in vitro (Brown et al. 2002). Exposure of rat islets to elevated plasma NEFA concentration, which has long-term (inhibitory) and short-term (stimulatory) effects on glucose-stimulated insulin secretion, did increase UCP2 abundance (Lameloise et al. 2001). This contrasts with our negative association between mean plasma NEFA and pancreatic UCP2 following leptin administration, suggesting a decrease in UCP2 may allow the pancreatic $\beta$-cells to resist the detrimental effects of high NEFA exposure (Dubois et al. 2004, Joseph et al. 2004). Increased NEFA metabolism leads to an increase in energy flux through the electron transport chain, which can lead to enhanced production of reactive oxygen species in $\beta$-cells (Carlsson et al. 1999, Barbu et al. 2002). UCP2 may be involved in this interaction by limiting the NEFAstimulated increase in reactive oxygen species production by dissipating the excess energy by activating proton transport mechanisms at the matrix side of the mitochondrial inner membrane (Echtay et al. 2002). The positive association between UCP2 and VDAC and cytochrome $c$ proteins may be important in regulating the ATP/ADP ratio in $\beta$-cells, which also controls insulin secretion (Sweet et al. 2004). The recent localisation of VDAC in the plasma membrane (Bahamonde \& Valverde 2003), its possible role in fluid secretion (Buettner et al. 2000) and its presence in the human pancreas (Huizing et al. 1998), suggest an additional role for VDAC in insulin secretion by $\beta$-cells - a role possibly enhanced by leptin, in view of the

Table 3 Significant relationships in the pancreas, liver, skeletal muscle and cerebral cortex between fetal plasma leptin and physiological and molecular indices measured in sheep neonates subjected to i.v. leptin (100 $\mu \mathrm{g} /$ day) or vehicle for 6 days ( $n=8$ per group)

\begin{tabular}{|c|c|c|c|c|c|c|}
\hline & Group & $x$ axis & $y$ axis & $\boldsymbol{R}^{2}$ & $P$ value & Relationship \\
\hline \multicolumn{7}{|l|}{ Tissue } \\
\hline Pancreas & Vehicle & VDAC & UCP2 protein & $0 \cdot 37$ & 0.034 & - \\
\hline Pancreas & Leptin & VDAC & UCP2 protein & $0 \cdot 74$ & $0 \cdot 015$ & + \\
\hline Pancreas & Leptin & Cytochrome C & UCP2 protein & $0 \cdot 75$ & $0 \cdot 036$ & + \\
\hline Pancreas & Leptin & Mean plasma NEFA over 7 days & UCP2 protein & $0 \cdot 42$ & 0.047 & - \\
\hline Pancreas & Leptin & Plasma leptin on day 7 & VDAC & $0 \cdot 39$ & $0 \cdot 014$ & + \\
\hline Liver & Leptin & Plasma leptin on day 7 & VDAC & $0 \cdot 45$ & $0 \cdot 036$ & + \\
\hline Liver & Leptin & Cytochrome $\mathrm{C}$ & VDAC & $0 \cdot 34$ & $0 \cdot 046$ & + \\
\hline Muscle & Leptin & Plasma leptin on day 7 & VDAC & $0 \cdot 70$ & $0 \cdot 019$ & + \\
\hline Muscle & Vehicle & Plasma leptin on day 7 & Cytochrome $\mathrm{C}$ & 0.67 & $0 \cdot 032$ & - \\
\hline Muscle & Leptin & Plasma leptin on day 7 & Cytochrome $\mathrm{C}$ & $0 \cdot 96$ & $<0.0001$ & + \\
\hline Muscle & Leptin & Mean colonic temperature over 7 days & GDP binding & $0 \cdot 51$ & $0 \cdot 042$ & + \\
\hline Brain & Leptin & Mean colonic temperature over 7 days & UCP2 protein & $0 \cdot 38$ & $0 \cdot 048$ & + \\
\hline
\end{tabular}


positive association between VDAC and plasma leptin on day 7 in the leptin group alone. Overall, these effects of leptin administration may be important in maintaining and protecting $\beta$-cell function. In this regard, leptin-deficient ob/ob mice have $\beta$-cell dysfunction (Lee \& Romsos 2003).

\section{Leptin and the neonatal brain, skeletal muscle and liver}

UCP2 was detected in the cerebral cortex of the neonatal sheep, although unaffected by leptin administration. In the rodent and primate brain, UCP2 is expressed predominantly in neuronal populations of subcortical regions that are involved in the central regulation of autonomic, endocrine and metabolic processes (Horvath et al. 1999, Diano et al. 2000). There is also a positive correlation between these areas and a high local brain temperature (Horvath et al. 1999). While the effects of chronic leptin administration on UCP2 abundance in the cerebral cortex have not been previously determined, leptin receptors have been co-localised to similar subcortical regions, through which leptin regulates appetite, energy balance and sympathetic nervous system activity (Della-Fera et al. 2001). Recently, circulating leptin has been proposed to mediate lipopolysaccharide-induced anorexia and fever in the rat, probably through a hypothalamic interleukin-1 $\beta$ dependent mechanism (Sachot et al. 2004). The stimulation of UCP2 transcription by the pyrogenic cytokines tumour necrosis factor- $\alpha$ and interleukin- $1 \beta$, which are also known to increase serum leptin levels in vivo (Zumbach et al. 1997, Faggioni et al. 1998b), suggests a similar role for UCP2 lipopolysaccharide-induced fever (Faggioni et al. 1998a). The positive association between UCP2 in the cerebral cortex and the mean colonic temperature over 7 days in the leptin group, suggests that such a mechanism, possibly involving interleukin-1 $\beta$, may be involved in the maintenance of colonic temperature despite the loss of UCP1 in neonatal BAT following chronic leptin administration in sheep (Mostyn et al. 2002).

In this present study, UCP2 was not detected in the neonatal liver or skeletal muscle, in agreement with Pecqueur et al. (2001), but in contrast to rodent studies that have only confirmed UCP2 mRNA abundance and its potential regulation by leptin in the liver and skeletal muscle (Cusin et al. 1998, Combatsiaris \& Charron 1999, Ricquier \& Bouillaud 2000) although the specificity of the antibodies used in these studies remains to be established. However, while UCP2 mRNA is widely expressed in a variety of tissues (Ricquier \& Bouillaud 2000), the protein expression is limited to a few organs, due to translational regulation of the UCP2 mRNA by an upstream open reading frame located in exon two of the UCP2 gene which strongly inhibits the expression of the protein (Pecqueur et al. 2001). Moreover in the present study, the effects of leptin administration appear to be specific to the inner mitochondrial protein UCP2, since VDAC and cytochrome $c$ proteins, although present in all the tissues examined, were unaffected by leptin administration, which is in agreement with previous findings in neonatal sheep BAT following chronic leptin administration (Mostyn et al. 2002). Interestingly the positive associations between plasma leptin and VDAC and cytochrome $c$ proteins in the pancreas, liver and skeletal muscle following leptin administration were only observed when plasma leptin had returned to basal concentration in these previously leptin-treated animals. It is therefore possible that although leptin had no direct effect on the abundance of these mitochondrial proteins, previous exposure to high leptin could potentially maximise either VDAC or cytochrome $c$ abundance in that individual. This may explain why, for example, the abundance of cytochrome $c$ was negatively correlated with basal leptin in controls but positively correlated in those animals given leptin. Ultimately this adaptation may imply augmented energy production within these organs following leptin administration (Lehninger et al. 1993, Crompton 1999, Gottlieb 2000). Indeed, the positive association between GDP binding and mean colonic temperature over 7 days in the skeletal muscle following leptin administration, suggests a possible role in thermogenesis; however, this would appear to be minor in comparison with neonatal BAT, which has markedly higher GDP binding activity, a reflection of the much greater potential thermogenic capacity.

In conclusion, we have shown for the first time that leptin administration to the neonate has tissue-specific effects on the abundance of UCP2. These effects may be important in the regulation of neonatal tissue development and potentially for optimising metabolic control mechanisms in later life.

\section{Funding}

This work was funded in part by the Nottingham University Hospitals Research and Development Directorate, and A M by a University of Nottingham Scholarship. The authors declare that there is no conflict of interest that would prejudice the impartiality of this scientific work.

\section{References}

Ahima RS \& Flier JS 2000 Adipose tissue as an endocrine organ. Trends in Endocrinology and Metabolism 11 327-332.

Bahamonde MI \& Valverde MA 2003 Voltage-dependent anion channel localises to the plasma membrane and peripheral but not perinuclear mitochondria. European Journal of Physiology 446 309-313.

Barbu A, Welsh N \& Saldeen J 2002 Cytokine-induced apoptosis and necrosis are preceded by disruption of the mitochondrial membrane potential (Deltapsi(m)) in pancreatic RINm5F cells: prevention by Bcl-2. Molecular and Cellular Endocrinology 190 75-82.

Bispham J, Budge H, Mostyn A, Dandrea J, Clarke L, Keisler D, Symonds ME \& Stephenson T 2002 Ambient temperature, maternal dexamethasone, and postnatal ontogeny of leptin in the neonatal lamb. Pediatric Research 52 85-90. 
Brown JEP, Thomas S, Digby JE \& Dunmore SJ 2002 Glucose induces and leptin decreases expression of uncoupling protein-2 mRNA in human islets. FEBS Letters 513 189-192.

Bryson JM, Phuyal JL, Swan V \& Caterson ID 1999 Leptin has acute effects on glucose and lipid metabolism in both lean and gold thioglucose-obese mice. American Journal of Physiology Endocrinology and Metabolism 277 E417-E422.

Buettner R, Papoutsoglou G, Scemes E, Spray DC \& Dermietzel R 2000 Evidence for secretory pathway localization of a voltage-dependent anion channel isoform. PNAS 97 3201-3206.

Carlsson C, Hakan Borg LA \& Welsh N 1999 Sodium palmitate induces partial mitochondrial uncoupling and reactive oxygen species in rat pancreatic islets in vitro. Endocrinology 140 3422-3428.

Cetin I, Morpurgo PS, Radaelli T, Taricco E, Cortelazzi D, Belloti M, Pardi G \& Beck-Peccoz P 2000 Fetal plasma leptin concentrations: relationship with different intrauterine growth patterns from 19 weeks to term. Pediatric Research 48 646-651.

Chan C, MacDonald P, Saleh M, Johns D, Marban E \& Wheeler M 1999 Overexpression of uncoupling protein 2 inhibits glucose-stimulated insulin secretion from rat islets. Diabetes $\mathbf{4 8}$ 1482-1486.

Clarke L, Darby CJ, Lomax MA \& Symonds ME 1994 Effect of ambient temperature during 1 st day of life on thermoregulation in lambs delivered by cesarean section. Journal of Applied Physiology $\mathbf{7 6}$ 1481-1488.

Clarke L, Heasman L, Firth K \& Symonds ME 1997a Influence of route of delivery and ambient temperature on thermoregulation in newborn lambs. American Journal of Physiology - Regulatory, Integrative and Comparative Physiology 272 R1931-R1939.

Clarke L, Buss DS, Juniper DS, Lomax MA \& Symonds ME 19976 Adipose tissue development during early postnatal life in ewe-reared lambs. Experimental Physiology 82 1015-1017.

Combatsiaris T \& Charron M 1999 Downregulation of uncoupling protein $2 \mathrm{mRNA}$ in white adipose tissue and uncoupling protein 3 mRNA in skeletal muscle during the early stages of leptin treatment. Diabetes 48 128-133.

Crompton M 1999 The mitochondrial permeability transition pore and its role in cell death. Biochemical Journal 341 233-249.

Cusin I, Zakrzewska KE, Boss O, Muzzin P, Giacobino J, Riquier D, Jeanrenaud B \& Rohner-Jeanrenaud F 1998 Chronic central leptin infusion enhances insulin-stimulated glucose metabolism and favours the expression of uncoupling proteins. Diabetes 47 1014-1019.

Delavaud C, Bocquier F, Chilliard Y, Keisler DH, Gertler A \& Kann G 2000 Effect of sheep nutritional status and body fatness on plasma leptin concentration assessed by a specific RIA. Journal of Endocrinology 165 519-526.

Della-Fera MA, Qian H \& Baile CA 2001 Adipocyte apoptosis in the regulation of body fat mass by leptin. Diabetes, Obesity and Metabolism 3 299-310.

Diano S, Urbanski HF, Horvath B, Bechman I, Kagiya A, Nemeth G, Naftolin F, Warden CH \& Horvath TL 2000 Mitochondrial uncoupling protein 2 (UCP2) in the nonhuman primate brain and pituitary. Endocrinology 141 4226-4238.

Dubois M, Kerr-Conte J, Gmyr V, Bouckenooghe T, Muharram G, D'Herbomez M, Martin-Ponthieu A, Vantyghem MC, Vandewalle B \& Pattou F 2004 Non-esterified fatty acids are deleterious for human pancreatic islet function at physiological glucose concentration. Diabetologia 47 463-469.

Echtay KS, Murphy MP, Smith RAJ, Talbot DA \& Brand MD 2002 Superoxide activates mitochondrial uncoupling protein 2 from the matrix side. Studies using targeted antioxidants. Journal of Biological Chemistry 277 47129-47135.

Emilsson V, Liu Y-L, Cawthorne MA, Morton NM \& Davenport M 1997 Expression of the functional leptin receptor mRNA in pancreatic islets and direct inhibitory action on insulin secretion. Diabetes 46 313-316.
Faggioni R, Shigenaga J, Moser A, Feingold KR \& Grunfeld C 1998a Induction of UCP2 gene expression by LPS: potential mechanism for increased thermogenesis during infection. Biochemical and Biophysical Research Communications 244 75-78.

Faggioni R, Fantuzzi G, Fuller J, Dinarello CA, Feingold KR \& Grunfeld C $1998 b$ IL- $\beta$ mediates leptin induction during inflammation. American Journal of Physiology - Regulatory, Integrative and Comparative Physiology 274 R204-R208.

Fleury C, Neverova M, Collins S, Raimbault S, Champigny O, Levi-Meyrueis C, Bouillaud F, Seldin MF, Surwit RS, Riquier D et al. 1997 Uncoupling protein-2: a novel gene linked to obesity and hyperinsulinaemia. Nature Genetics 15 269-272.

Friedman JM \& Halaas JL 1998 Leptin and the regulation of body weight in mammals. Nature 395 736-770.

Gertler A, Simmons J \& Keisler DH 1998 Large scale preparation of biologically active recombinant ovine obese protein (leptin). FEBS Letters 422 127-140.

Gnanalingham MG, Mostyn A, Dandrea J, Yakubu DP, Symonds ME \& Stephenson T 2005 Ontogeny and nutritional programming of uncoupling protein-2 (UCP2) and glucocorticoid receptor (GR) mRNA in the ovine lung. Journal of Physiology 565 159-169.

Gong DW, He Y, Karas M \& Reitman M 1997 Uncoupling protein-3 is a mediator of thermogenesis regulated by thyroid hormone, $\beta 3$-adrenergic agonists, and leptin. Journal of Biological Chemistry 272 24129-24132.

Gottlieb RA 2000 Mitochondria: execution central. FEBS Letters 482 6-12.

Horvath TL, Warden CH, Hajos M, Lombardi A, Goglia F \& Diano S 1999 Brain uncoupling protein 2: uncoupled neuronal mitochondria predict thermal synapses in homeostatic centers. Journal of Neuroscience 19 10417-10427.

Huizing M, Ruitenbeek W, van den Heuvel LP, Dolce V, Iacobazzi V, Smeitink JAM, Palmieri F \& Frans Trijbels JMF 1998 Human mitochondrial transmembrane metabolite carriers: tissue distribution and its implication for mitochondrial disorders. Journal of Bioenergetics and Biomembranes 30 277-284.

Jiang X \& Wang X 2004 Cytochrome-c mediated apoptosis. Annual Review of Biochemistry 73 87-106.

Joseph JW, Koshkin V, Saleh MC, Sivitz WI, Zhang C-Y, Lowell BB, Chan CB \& Wheeler MB 2004 Free fatty acid-induced $\beta$-cell defects are dependent on uncoupling protein 2 expression. Journal of Biological Chemistry 279 51049-51056.

Kieffer TJ, Heller RS \& Habener JF 1996 Leptin receptors expressed on pancreatic $\beta$-cells. Biochemical and Biophysical Research Communications 224 522-527.

Lameloise N, Muzzin P, Prentki M \& Assimacopoulos-Jeannet F 2001 Uncoupling protein 2: a possible link between fatty acid excess and impaired glucose-induced insulin secretion? Diabetes 50 803-809.

Lee J-W \& Romsos DR 2003 Leptin administration normalizes insulin secretion from islets of Lep(ob)/Lep(ob) mice by food intake-dependent and-independent mechanisms. Experimental Biology and Medicine 228 183-187.

Lehninger AL, Nelson DL \& Cox MM 1993 Oxidative phosphorylation and photo phosphorylation. In Principles of Biochemistry, pp 542-597. Ed. E Geller. New York: Worth Publishers.

Litten JC, Mostyn A, Perkins KS, Corson AM, Symonds ME \& Clarke L 2004 The effect of administration of recombinant human leptin during the neonatal period on the plasma concentration and gene expression of leptin in the piglet. Biology of the Neonate 87 1-7.

Lowry OH, Rosenbrough NJ, Farr AL \& Randall RJ 1951 Protein measurement with the Folin phenol reagent. Journal of Biological Chemistry 193 265-275.

Ludwig B, Bender E, Arnold S, Huttemann M, Lee I \& Kadenbach B 2001 Cytochrome $\mathrm{c}$ oxidase and the regulation of oxidative phosphorylation. Chembiochem 2 392-403.

Memon RA, Hotamisligil GS, Wiesbrock SM, Uysal KT, Faggioni R, Moser AH, Feingold KR \& Grunfeld C 2000 Upregulation of 
uncoupling protein $2 \mathrm{mRNA}$ in genetic obesity: lack of an essential role for leptin, hyperphagia, increased tissue lipid content, and TNF- $\alpha$. Biochimica et Biophysica Acta 1484 41-50.

Mostyn A, Bispham J, Pearce S, Evens Y, Raver N, Keisler DH, Webb R, Stephenson T \& Symonds ME 2002 Differential effects of leptin on thermoregulation and uncoupling protein abundance in the neonatal lamb. FASEB Journal 16 1438-1440.

Mostyn A, Wilson V, Dandrea J, Yakubu DP, Budge H, Alves-Guerra MC, Pecqueur C, Miroux B, Symonds ME \& Stephenson T 2003 Ontogeny and nutritional manipulation of mitochondrial protein abundance in adipose tissue and the lungs of postnatal sheep. British Journal of Nutrition 90 323-328.

Nedergaard J \& Cannon B 2003 The 'novel' 'uncoupling' proteins UCP2 and UCP3: what do they really do? Pros and cons for suggested functions. Experimental Physiology 88 65-84.

Nonogaki K 2000 New insights into sympathetic regulation of glucose and fat metabolism. Diabetologia 43 533-549.

Pecqueur C, Alves-Guerra M, Gelly C, Levi-Meyrueis C, Couplan E, Collins S, Ricquier D, Bouillaud F \& Miroux B 2001 Uncoupling protein 2: in vivo distribution, induction upon oxidative stress and evidence for translational regulation. Journal of Biological Chemistry 276 8705-8712.

Pelleymounter MA, Cullen MJ, Baker MB, Hecht R, Winters D, Boone T \& Collins F 1995 Effects of the obese gene product on body weight regulation in ob/ob mice. Science $269540-543$.

Phillips AF, Carson BS, Meschia G \& Battaglia FC 1978 Insulin secretion in fetal and new born sheep. American Journal of Physiology - Endocrinology and Metabolism 235 E467-E474.

Qian H, Azain MJ, Compton MM, Hartzell DL, Hausman GJ \& Baile CA 1998 Brain administration of leptin causes deletion of adipocytes by apoptosis. Endocrinology 139 791-794.

Ricquier D \& Bouillaud F 2000 The uncoupling protein homologues: UCP1, UCP2, UCP3, StUCP and AtUCP. Biochemical Journal 345 161-179.

Roduit R \& Thorens B 1997 Inhibition of glucose-induced insulin secretion by long term preexposure of pancreatic islets to leptin. FEBS Letters 415 179-182.

Sachot C, Poole S \& Luheshi GN 2004 Circulating leptin mediates lipopolysaccharide-induced anorexia and fever in rats. Journal of Physiology $561263-272$.
Scarpace P, Matheny M, Pollock B \& Tumer N 1997 Leptin increases uncoupling protein expression and energy expenditure. American Journal of Physiology - Endocrinology and Metabolism 273 E226-E230.

Schwartz MW, Seeley RJ, Campfield LA, Burn P \& Baskin DG 1996 Identification of targets of leptin action in rat hypothalamus. Journal of Clinical Investigation 98 1101-1106.

Sivitz WI, Walsh SA, Morgan DA, Thomas MJ \& Haynes WG 1997 Effects of leptin on insulin sensitivity in normal rats. Endocrinology 138 3395-3401.

Sweet IR, Cook DL, DeJulio E, Wallen AR, Khalil G, Callis J \& Reems J 2004 Regulation of ATP/ADP in pancreatic islets. Diabetes 53 401-409.

Symonds ME, Bryant MJ, Clarke L, Darby CJ \& Lomax MA 1992 Effect of maternal cold exposure on brown adipose tissue and thermogenesis in the neonatal lamb. Journal of Physiology 455 487-502.

Yuen BSJ, McMillen IC, Symonds ME \& Owens PC 1999 Abundance of leptin mRNA in fetal adipose tissue is related to fetal body weight. Journal of Endocrinology 163 R11-R14.

Zhang CY, Baffy G, Perret P, Krauss S, Peroni O, Grujic D, Hagen T, Vidal-Puig AJ, Boss O, Kim YB et al. 2001 Uncoupling protein-2 negatively regulates insulin secretion and is a major link between obesity, beta cell dysfunction, and type 2 diabetes. Cell $105745-755$.

Zhou Y-T, Shimabukuro M, Koyama K, Lee Y, Wang M-Y, Trieu F, Newgard CB \& Unger RH 1997 Induction by leptin of uncoupling protein-2 and enzymes of fatty acid oxidation. PNAS 94 6386-6390.

Zumbach MS, Boehme MW, Wahl P, Stremmel W, Ziegler R \& Naworth PP 1997 Tumour necrosis factor increases serum leptin levels in humans. Journal of Clinical Endocrinology and Metabolism 82 4080-4082.

Received in final form 27 June 2005

Accepted 6 July 2005

Made available online as an Accepted Preprint

19 July 2005 